\title{
The Role of Technology in the Fresh-Water Pearl Button Industry of Muscatine, Iowa, 1891 - 1910
}

Jane A. Farrel-Beck

\section{Rebecca Hatfield Meints}

$W_{\text {hen button-making technology, introduced by John Fred }}$ Boepple, exploited the naturally abundant mussel shells provided by the Mississippi River, Muscatine's fresh-water pearl button industry flourished. Industrial growth followed with the technological improvements wrought by such inventors as William C. Hopkins and Fred Hopkins. That technology helped to establish the manufacture of fresh-water pearl buttons, but could not sustain the industry in the face of economic and societal change. Given the depletion of the mussel population, competition from Japan, labor troubles, and changes in women's fashions, the growth of Muscatine's industry could not endure.

Between 1855 and 1890, factories in the United States produced millions of pearl buttons - all of them from ocean pearl or "mother-of-pearl." Factories in port and industrial cities such as New York and Newark, New Jersey, converted into buttons the pearl imported from China, Western and Southern

This study is journal paper no. 275 of the Home Economics Research Institute, Iowa State University. 
Australia, New Guinea, Burma, the Philippines, North Queensland, Thursday Island, and the Arafua Sea. In 1891 fresh-water pearl began to challenge the supremacy of ocean pearl; by 1905, two-thirds of the pearl buttons produced in the United States came from fresh-water pearl. ${ }^{1}$ Furthermore, pearl buttons of both materials constituted almost half of all buttons made domestically. Iowa factories accounted for 39 percent of product value among the three largest producing states (New York and New Jersey completed the trio). Although the two eastern states had existing button-making plants ready to process the raw materials, Iowa had J. F. Boepple and arguably the most abundant deposits of the mussel (Unios) shells ideal for button making. ${ }^{2}$ Muscatine claimed the first fresh-water pearl button industry in the United States and remained the center of the industry. Eventually, the Iowa towns of Cedar Rapids, Vinton, Charles City, Coralville, West Liberty, What Cheer, and Oskaloosa boasted their own button works.

With so many factories turning out a supply, a demand must have existed and what a demand it was! Between 1891 and 1910 buttons of pearl adorned men's shirts; women's "waists" (blouses); washable dresses for women and children; drawers, petticoats, and corset covers; and "dusters," the coats worn for "motoring." All of these classes of garments rolled off domestic assembly lines in mass quantities, so the demand for buttons was huge. ${ }^{3}$ The 1893 figures on ocean pearl give some idea of the volume: With the price per gross ranging from forty cents to twenty-five dollars wholesale, the annual consumption

1. "Mother of Pearl Industry," Scientific American Supplement 55 (28 March 1903), 22766; Axel Josephsson, "The Fresh-water Pearl Button Industry," Scientific American Supplement 65 (20 June 1908), 386; "The Pearl Button: Light on a Great Industry," Scientific American Supplement 67 (29 May 1909), 350.

2. Hugh M. Smith, "The Pearl Button Industry of the Mississippi," Scientific American 81 (5 August 1899), 86-87. Smith may have been a biologist at Woods Hole, Massachusetts, assigned by the U. S. Fish Commission to study the Muscatine industry.

3. Harper's Bazar [sic], 1891-1910 passim; Claudia Kidwell and Margaret C. Christman, Suiting Everyone: The Democratization of Clothing in America (Washington, D. C., 1974). 


\section{Technology in the Button Industry}

amounted to fully $\$ 3.5$ million retail or about $\$ 1.175$ million wholesale. $^{4}$

When the fresh-water pearl button industry emerged in 1891, this new and cheaper material began to engross much of the waiting market. If anything, demand rose sharply after 1893, encouraged by expanding population, favorable pricing due to tariffs, and an ever-growing domestic clothing industry. Both native-born and immigrant people swelled the United States' population in the late nineteenth and early twentieth centuries. Central, eastern, and southern Europeans flocked to America and struggled to survive and blend into the rest of the population. To do the latter, they needed clothes that looked like those of "real" Americans, not the raiment of "greenhorns"; as soon as immigrants passed the level of bare subsistence, they bought new clothes. After the Spanish-American War, slowly spreading prosperity nurtured an increasing middle class of citizens. Given inconsequential inflation, these Americans spent their wages on such luxuries as better quality and greater variety of clothes.

Tariffs set in 1890 and 1897 on all imported buttons made the domestic ones competitive and helped the industry to grow. ${ }^{5}$ Finally, those incoming European immigrants provided a cheap and abundant pool of labor to make domestic "needle trades" boom. Clearly, the times favored the establishment of a pearl button industry.

When John Fred Boepple came to Muscatine in about 1884, he found a thriving community. ${ }^{6}$ By 1890 its population reached 11,454; local businesses included a plumbing supply company, an awning factory, a sash and door company, a flour mill, a woven wire works, and a clay pipe plant. Lumbering dominated

4. "The Pearl Button Industry," Scientific American 68 (29 April 1893), 260-261.

5. E. Stanwood, American Tariff Controversies in the Nineteenth Century, vol. 2 (Cambridge, MA, 1903). More information on tariff history can be obtained from Frederick Taussig, The Tariff History of the United States (New York, 1931).

6. Irving B. Richman, ed., The History of Muscatine County, vol. 1 (Chicago, 1911); O. Longstreth, "The Button Industry of Iowa," unfinished 
local commerce; Muscatine sawmills processed cut logs into lumber. Decline threatened that industry, however, due to the exhaustion of Minnesota and Wisconsin white pine forests. Muscatine needed a new industry.

Boepple, a native of Ottensea, Germany, came to the United States seeking a source of fresh-water pearl. In Hamburg he had been trained in the manufacture of buttons, especially from this material. With the encouragement of Frank Keakeritz, a Muscatine jeweler, and the modest financial backing of William Molis, superintendent of the waterworks, Boepple set up his first tiny factory. ${ }^{7}$ This early partnership failed to show a profit, apparently because of the difficulties of perfecting the machinery to make a marketable button, but Boepple continued to experiment with making buttons in his home. Eventually he was able to recreate the Austro-German methods and tools he had known - such as the foot-powered lathe. Locally abundant Unios shells, coupled with the relatively simple machinery, launched a booming local industry, spurring not only buttonmaking but also mussel fishing, cutting unfinished blanks for buttons, and manufacturing machinery for making buttons. ${ }^{8}$

From 1891 to 1898, workers used a combination of methods to gather shells and convert them into buttons. Freshwater mussel fishermen worked with a long shallow "john boat," with square ends, and three different tools to gather mussels - the rake, the tongs, and the crowfoot. The rake had a long handle and a basket behind the tines; a fisherman lowered it to the river bottom and scooped up mussels. Others chose to use the tongs, which resembled two long rakes fastened together; they dropped the tongs into the water and closed them around batches of mussels. The crowfoot consisted of a long pipe with attached fish line, from which hung crowfoot-shaped

M.A. thesis, 1906, Manuscript Collections, State Historical Society of Iowa, Iowa City. Longstreth reported 1888 as Boepple's arrival date in the United States. Since this was an unpublished source, not subject to "correction," we chose the Richman date.

7. Longstreth, "Button Industry."

8. Smith, "Button Industry of the Mississippi"; Josephsson, "Fresh-water Pearl Button Industry." 


\section{Technology in the Button Industry}

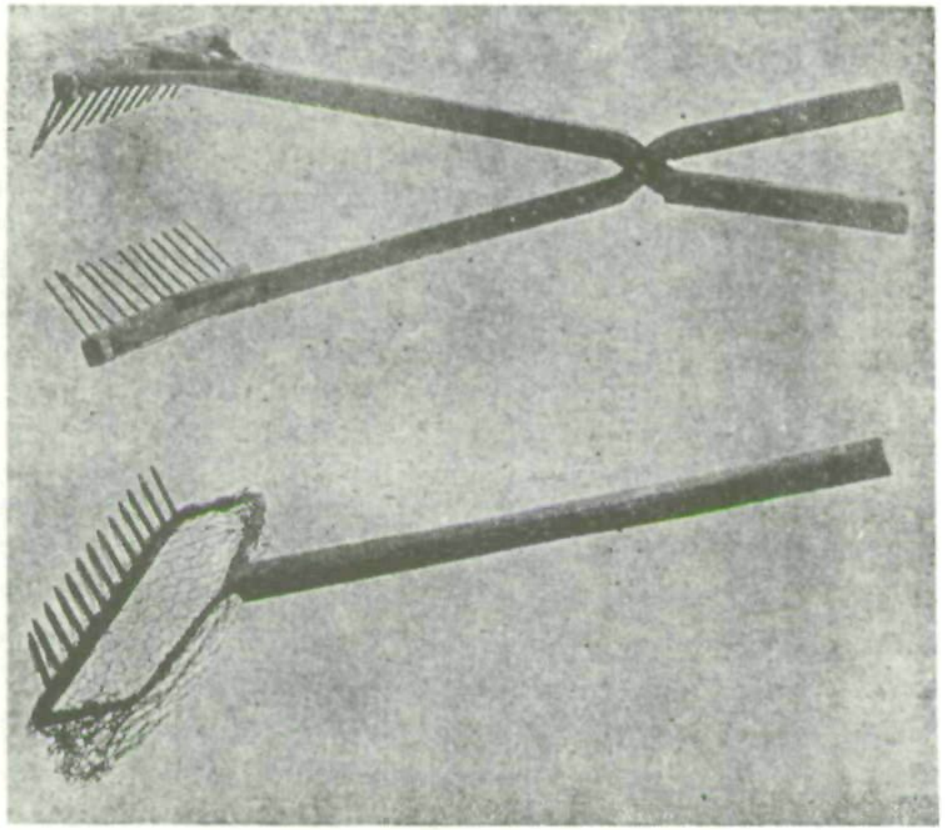

Mussel gatherers used tools such as the tongs (above) and the rake (below.)

hooks. When a "clammer" dropped this device into the water and dragged it along the bottom, mussels clamped onto the hooks and could be pulled to the surface. Once they had gathered the mussels, the clammers took their catch to shore, steamed the mussels open, partially cleaned them, and sorted them by species. ${ }^{9}$

About twelve different species of mussels made acceptable buttons, but the quality of the button varied with the shell's thickness, evenness of color, and toughness in withstanding cutting without cracking or splitting. Buttonmakers prized the so-

9. Hugh Smith, "The Mussel Fishery and Pearl Button Industry of the Mississipppi," United States Fish Commission Bulletin (Washington, D. C., 1898); T. P. Giddings, "Clamming along the Mississippi," Outing Magazine 50 (July 1907), 473-479; Marie Haefner, "Argonauts of the Mississipppi," The Palimpsest 13 (December 1932), 473-486; Josephsson, "Fresh-water Pearl Button Industry." 
called "niggerheads" for the thick, snowy inner layers (nacre) that made the fine iridescent buttons. "Muckets," "deerhorns," and "butterflies" also provided significant volumes of salable buttons. ${ }^{10}$

At the factory, workers soaked the mussels in water to remove any remaining flesh and to maintain shells in flexible condition for drilling. Other operatives took the shells from the tanks to their saws and cut button blanks from them, striving to get from each shell as many usable cylinders as possible. Workers cut the shells with tubes that had serrated ends, against which each shell was pressed. Next, the cutter sorted blanks according to size and ground them to uniform thickness. Then another worker placed the blanks under a lathe with carving tools that cut designs in the outer face of each button. Women workers drilled holes in the buttons and finished them by polishing in dilute muriatic acid and tumbling in both pumice and sawdust. Dyers imparted fashionable colors to some of the buttons, using aniline (coal tar derivative) dyes. Women workers boxed the finished buttons to sell in bulk, usually to garment manufacturers, or sewed them onto cards for retail customers. ${ }^{11}$

$I_{\text {NCREMENTS OF EFFICIENCY came quickly, as inventors refined }}$ the tools and machines for gathering and converting the shells. The crowfoot itself represented an improvement over the older rake and tongs. In the spring of 1897 , some unknown innovator introduced the crowfoot, which became the favored tool because it caught only the live mussels that clamped onto the hooks. Factory workers could cut the shells taken from live mussels much more easily than the brittle shells from dead ones. The steam dredge came into use around 1897, too, but found less favor than the crowfoot; the dredge did not work well in the shallow river beds where the mussels thrived. ${ }^{12}$

Small but significant improvements modified the cutting machinery. Boepple found that his original foot-powered

10. Smith, "Pearl Button Industry of the Mississippi."

11. Smith, "Mussel Fishery and Button Industry"; Longstreth, "Button Industry."

12. Ibid. 
treadle machines did not cut efficiently, so he brought in steam power when he expanded his factory in 1894. A belt connected each machine to a jackshaft near the ceiling of the factory. These ceiling shafts in turn connected to the main shaft, turned by a single large steam engine. Steam furnished power for several of the large factories; other plants used electricity generated by coal in the city plant or in private generators. Small factories ran with two- or three-horsepower gasoline engines to cut the blanks. ${ }^{13}$

The only other significant improvement in cutting machinery occurred around 1900 . Until that time, the dust that came from sawing the blanks blew out of the factories by exhaust fans. An attachment to the saw reduced the need for fans, while controlling the dust more effectively, although not eradicating it. A nozzle with a rubber hose or pipe extended from the saw on the side nearest the mussel shell. It shot a stream of water onto the area of the shell being cut. The nozzle rotated on a ball socket to direct the water wherever the cutter needed it. ${ }^{14}$

Larger technological changes in the industry altered the button finishing process. In 1891 converting a blank to a button entailed completely separate operations to grind the blank to uniform thickness, face it, drill holes, and polish it. Innovations improved the methods of facing and drilling. The first improvement consisted of adding moving chucks or clamps of wood to the facing and drilling machine. ${ }^{15}$ Each chuck held one blank and passed it under the tools of the machine. The operator directed the chucks and centered the tools on the blank. Each chuck stayed in position as it moved around the machine from facers to drillers. Then the blanks were manually distributed onto a conveyor belt and passed under an emery wheel for grinding, pearly side down.

13. Interview with William B. Hopkins, November 1980, Muscatine, Iowa; Longstreth, "Button Industry"; Smith, "Pearl Button Industry of the Mississippi." Hopkins, now an inventor for the McKee Button Company, is the son of William C. Hopkins, cutting foreman at the McKee and Bliven Button Company from 1898 to 1948.

14. Longstreth, "Button Industry."

15. Ibid. 


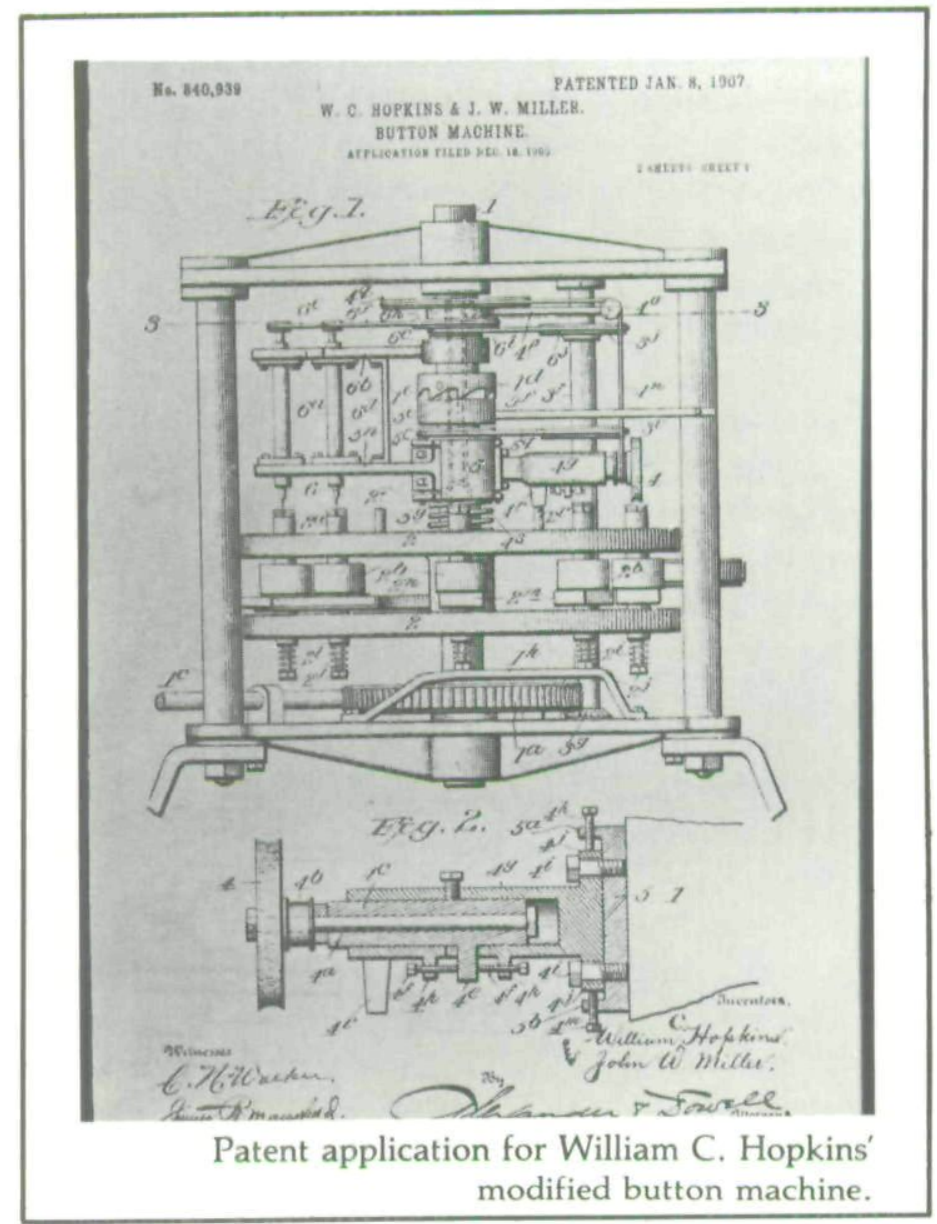

A second improvement, the "Barry Automatic" finishing machine, came into use in 1900. The Barry Manufacturing Company of Muscatine produced this machine, which centered and drilled each faced blank. By 1902 a refined Barry Automatic included continuous adjustment and sharpening of the facing and drilling tools, which had formerly required the operators' continual attention.

The Barry Automatic faced the blanks using an individual tool to produce each part of the pattern. For patterns other than standard ones, workers had to resort to special attachments or hand tools. William C. Hopkins, cutting foreman for the McKee and Bliven Button Company for fifty years, modified the Barry 
Automatic to have a rotating chuck and cat's-eye attachment. ${ }^{16}$ Instead of staying stationary while moving through the machine, this chuck rotated in steps and allowed continuous patterns to be carved on the button face. The cat's-eye attachment cut long grooves on the button face. Then a separate tool drilled the holes. The button emerged from this composite machine almost complete.

Each tool remained a separate entity in the improved machine. Therefore, the blanks had to move through several positions for facing and drilling. Fred M. Hopkins, another employee of the McKee and Bliven Button Company, improved the Barry Automatic so that all tools were mounted onto a single plate. This machine performed the operations simultaneously on the blanks. ${ }^{17}$ The plate remained stationary while the chucks moved underneath it. By a further innovation, mechanisms fed the drills to the blanks gradually. This largely eliminated any marring of the carved surface and prevented the blanks from popping out of the chucks, as sometimes happened with the sudden application of drills.

Each of the improvements in technology reduced the cost of making the fresh-water pearl buttons. Workers could operate efficient machines and turn out buttons more speedily. Longstreth maintained that the Barry Automatic had reduced the cost of finishing buttons from four cents to one cent per gross by $1906 .{ }^{18}$ As each of these new machines appeared, those factories that could, adopted them. Smaller firms that could not afford to change machines - as often as once a year, according to some writers - eventually went out of business.

This voluminous production of machinery created another prosperous industry in Muscatine. Hugh M. Smith stated in

16. U. S. Department of Commerce, Patent Office, Patent 840,939 , William C. Hopkins, filed 18 December 1905. John W. Miller is listed as assignor to the McKee and Bliven Button Company, Muscatine, Iowa.

17. U. S. Department of Commerce, Patent Office, Patent 981,564, Fred M. Hopkins, patent filed 1 June 1906. The two assignors of one-third each of this patent are William C. Hopkins and Henry Umlandt, both of Muscatine, Iowa. The relationship of Fred Hopkins to William C. Hopkins has not been determined.

18. Longstreth, "Button Industry." 
1898 that ". . . at some large machine shops practically the entire work now consists in making and repairing apparatus used in button manufacturing and mussel fishing." He cited handsome profits as an incentive to the expansion of the machine shops: Cutting machines that cost $\$ 7.70$ to manufacture sold for $\$ 28$. A machinist could produce the equipment for a ten-saw plant for \$566.40, including overhead, and could sell the same outfit for between $\$ 2500$ and $\$ 3000 !^{19}$ Barry Manufacturing grew out of the experience of Nick, Tom, and Pat Barry in developing machinery to accomplish what Boepple was struggling to do: make a fresh-water pearl button of high quality. Originally Barry Manufacturing produced plumbing, heating, and gas fittings, but the plant sold out those interests and turned to the lucrative manufacture of button-making machinery. ${ }^{20}$

S Exual division of LABor prevailed within the industry; each task fell to male or female workers, with very little crossover of responsibilities. Men and adolescent boys cut blanks and ground, polished, and dyed the buttons. Women and adolescent girls faced, drilled, sorted, and packaged finished buttons. Each worker also had to sharpen and replace the tools in his or her machine. ${ }^{21}$ This seemed not to change drastically with the introduction of new machinery, although sharpening and adjusting tools became automatic.

Wages varied with the different tasks. Shell sorters received an hourly wage. Other workers earned their "piecework" pay by the gross of units completed. In this case a gross equaled fourteen dozen units, to compensate for poor quality ones. Factory managers calculated cutters' wages in two ways: first, by a scale that measured the blanks per line ( $1 / 40$ inch) per gross and second, by comparing the weight of the completed blanks to a box with one gross of blanks in it. ${ }^{22}$

19. Smith, "Pearl Button Industry of the Mississippi."

20. Haefner, "Argonauts of the Mississippi."

21. Interview with Hopkins.

22. "Button Men and Their Count," Labor's Voice 14 (February 1910), 4. In the first method an average weight per gross was established for each size (line) of button. The scale was set at the standard weight and the employee's 
Women's wages also accrued by the number of gross units completed. No sources cited specific wages but several mentioned "average" wages. Blank cutters earned about ten cents per gross or about ten to fifteen dollars per week. ${ }^{23}$ If Longstreth's citation about the cost-cutting effect of the Barry Automatic is correct, finishers must have received only about one cent per gross in 1906. These wages, however, beg contrast to the Japanese workers' pay in a less mechanized version of the same industry. In 1908-1909, these craftspeople earned the equivalent of one to four cents for each 1000 units, not each "gross" of 168 . As the Japanese added power machinery, which they had begun to do in 1908, they became formidable competitors to the Muscatine firms. ${ }^{24}$

By 1983 standards, employees worked long hours in the fresh-water pearl button industry. Between 54 and 60 hours per week constituted the norm for 2,868 of the 3,172 wage earners reported in the 1910 census. Unreported workers may have worked up to 72 hours per week. This does not represent unusually bad conditions for the period, when about 20 percent of iron and steel workers labored 84 hours per week and almost 43 percent of this same group of workers maintained a 72-hour week. Girls of sixteen years in New York state could work 60-hour work weeks in the garment industry and other manufacturing and could keep unlimited hours in selling positions during the "rush" season before Christmas. ${ }^{25}$

Button workers also had to contend with industrial hazards, chiefly the dust produced by the grinding of the shells. Dust irritated the bronchial tubes and the lungs and could, in

blanks were weighed. The second method involved taking a small quantity of blanks from the employee's work, counting the number of usable blanks, and using this as a standard weight to measure the worker's blanks. In both cases, the unusable blanks counted against the worker.

23. Longstreth, "Button Industry"; Haefner, "Argonauts of the Mississippi"; Smith, "Pearl Button Industry of the Mississippi."

24. "Pearl Button: Light on a Great Industry" (see fn. 1).

25. Kate Rousmaniere, "The Muscatine Button Workers' Strike of 1911-12: An lowa Community in Conflict," The Annals of lowa 46 (Spring 1982), 243-262; U. S. Census Office, Thirteenth Census of the United States Taken in the Year 1910, vol. 9. Manufactures. 
time, produce chronic bronchitis and pulmonary emphysema. ${ }^{26}$ Good exhaust fans reduced the dust, which the wet cutting of shells after 1900 further diminished. However, census mortality figures for 1900 through 1906 cited about 38 percent of deaths due to "consumption" among male button workers, while death from the same cause was about 15 percent among males in the general population. Obviously, dust-related disease continued to plague the fresh-water pearl button workers. ${ }^{27}$

Late in 1910 button workers began to succeed in their efforts to organize, spurred by grievances about wages and working conditions. According to Labor's Voice, a statewide monthly trade union paper, wildcat strikes had occurred often, as early as 1908. After sixteen months of effort, the Button Workers Protective Union Number 12854 became official. By 1911 the union and the Muscatine plant managers had come into open conflict. A recent study of the strike described it as precipitated by the shutdown of forty-three factories in the town. ${ }^{28}$ This provoked a fifteen-month boycott of the factories by unionized workers, who considered the shutdown a threat to their union, not a response to the overproduction of buttons or a depression of the eastern clothing factories, as the managers claimed. The grievances of the workers that emerged during the strike included sexual harassment of women workers, hazards from fire and from putrefaction in the shell-soaking vats, circumvention of child labor laws, and the dishonesty of plant managers in weighing buttons to calculate piecework pay. Both local and national support helped the workers sustain the strike for fifteen months, but violence did erupt. Strike breakers and state militia got into the act, and the confrontation ended in stalemate in the summer of 1912.

$\mathrm{O}$

VER THE TWENTY YEARS between 1891 and 1910, the button industry grew quickly. Boepple had the only factory in Muscatine from 1891 until at least 1895. By 1898, the Muscatine City

26. F. L. Hoffman, "Mortality From Consumption in Occupations Exposing to Municipal and Organic Dust," Bulletin of the Bureau of Labor 18 (1909), 471-638.

27. Thirteenth Census, 1912.

28. Rousmaniere, "Button Workers' Strike." 
Directory listed two additional button factories and three sawworks, which made only button blanks. These latter firms multiplied rapidly, numbering twenty-eight in Muscatine by mid-1898, compared to only five button plants operating that year. (See Table 1) Often the blank factories shipped their products to factories in New York and New Jersey for finishing into buttons. These same plants in the East had previously processed only ocean pearl into buttons. Muscatine also boasted one "button machinery" plant and one "button saw manufacturer" in 1898. Consolidation caused the number of blank-making firms to decline to ten in 1908, then rise to twenty-five in 1910. Apparently demand for blanks could be quite volatile in response to the demand for buttons, itself a function of the demands of fashion and the ability of consumers to buy clothes. According to the Muscatine City Directory, by 1908 twelve complete button plants operated in Muscatine; six of these had incorporated: Boepple Button Company, the Muscatine Pearl Company, the Muscatine Pearl Novelty Company, Richards-Smith Button Company, Hawkeye Pearl Button Company, and the Pioneer Pearl Button Company. Bishop and Hagerman Company, a blank cutting firm, had also incorporated. Statewide (no local figures were available), the industry in 1910 encompassed seventy factories, 3,376 employees, a product value of $\$ 4,035,000$, and wages of $\$ 1,412,000$. Rousmaniere's citation of forty-three button plants closing in 1911 suggests that proportionately two-thirds of each of these figures might have pertained to Muscatine. ${ }^{29}$

Growth brought problems that, in the long term, undermined the industry. In 1898, only seven years after Boepple's beginning, Hugh Smith was warning that overfishing, taking of undersized mussels, and year-round fishing (including ice fishing) had seriously depleted the mussel population. Already, shells had to be imported from Missouri and Illinois because of the decline in mussels in the Mississippi River around Muscatine. Overfishing did damage, made worse by pollution, depleting the supply of oxygen in the rivers. Another abuse involved tossing dead mussels back into the water, covering the

29. Ibid. 


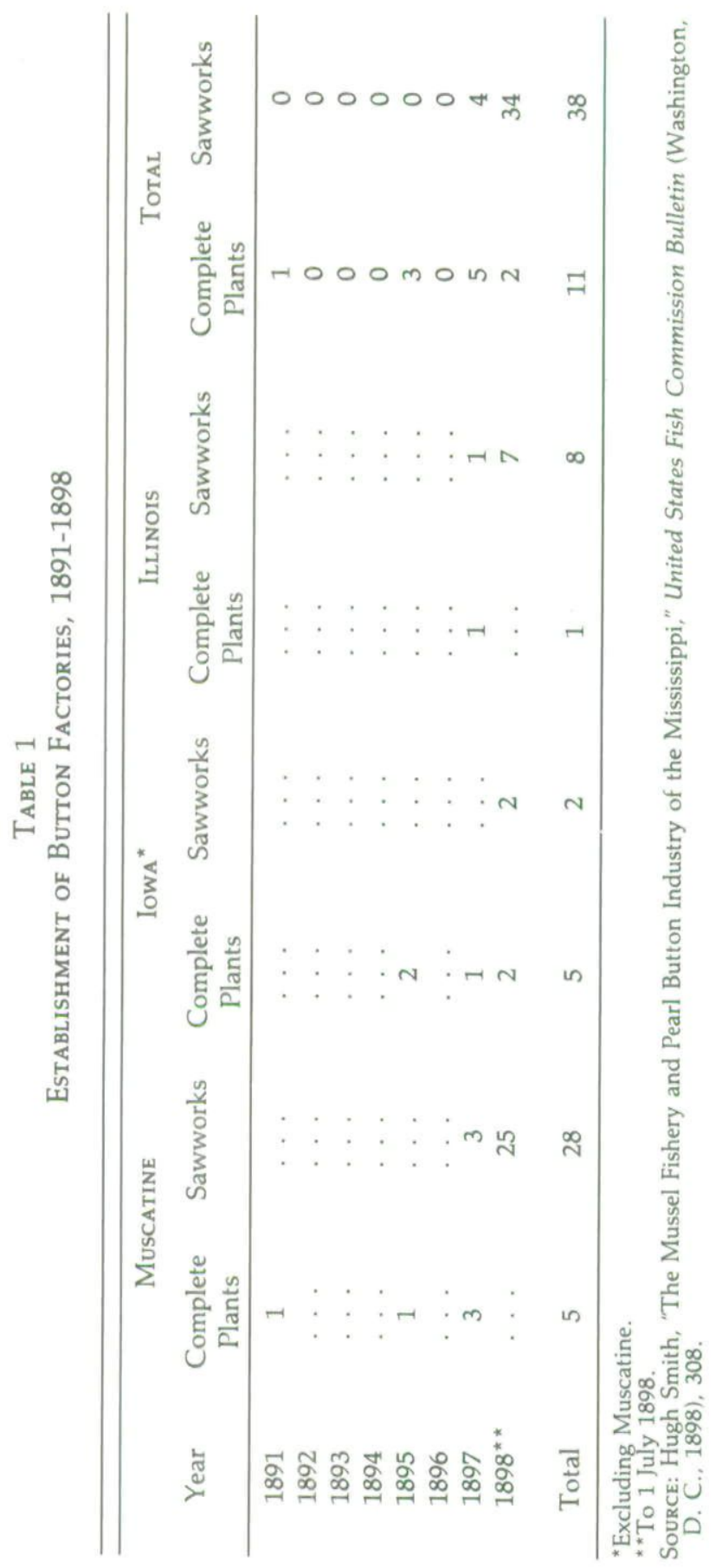


live ones, and interfering with their respiration and feeding. ${ }^{30}$

Smith recommended a legal limit on the size of mussels that could be taken, a closed season on mussel fishing (breeding time), and limiting exports to other states. ${ }^{31}$ Although the United States Fish Commission published this report, it took no action on the recommendations. In 1907 Congress finally reopened the matter. Out of this "further study" emerged the biological station at Fairport, in Muscatine County. This station studied and promoted the propagation of fresh-water mussels. Other stations followed Fairport's 1910 lead. By 1921 an unnamed number of biological stations could propagate and bring mussels to commercial size in two to three years. A report of these figures in Scientific American Monthly remained confident of the enduring supply of mussels; this optimism did not prevent the decline of the industry. ${ }^{32}$ Complex causes contributed to that decline: the erosion of mussel supplies, competition from Japan, continuing poor industrial relations after the 1911-1912 strike, and inevitable changes of fashion after about 1913.

In 1921 Roberts called for a protective tariff to be levied against fresh-water pearl buttons imported from Japan. The Japanese had fulfilled the promise - or threat - of mechanizing their button industry. Labor costs, which constituted a large part of the expense of producing buttons, were very much lower in Japan than in the United States. As a result of this vigorous competition, Muscatine factories could only operate at an average 40 percent of capacity in 1921 and 1922 . By 1923 the tariff against Japanese buttons took effect and Muscatine production rose to 50 percent of capacity, being expected to rise further when stores of Japanese buttons had been consumed. ${ }^{33}$ Even by 1932, however, the industry had not rebounded to its former strength.

A fourth, perhaps the most powerful, force against the

30. Smith, "Pearl Button Industry of the Mississippi"; Longstreth, "Button Industry."

31. Smith, "Pearl Button Industry of the Mississippi."

32. S. G. Roberts, "America's Fresh-water Pearl Button Industry," Scientific American Monthly 4 (September 1921), 100-103.

33. Ibid.; Haefner, "Argonauts of the Mississippi." 
revival of Muscatine's button-making enterprises was fashion. Significantly, in her 1932 Palimpsist article, Marie Haefner cited 1916 as the peak year of the industry; after about 1914, women's clothes evolved toward designs that did not favor buttons on the scale of those made from fresh-water pearl-buttons of one inch or less in diameter. The large buttons of the next twentyfive years used materials such as plastic, metal, ceramic, leather, and cloth. Some blouses and lingerie still had small buttons, but these counted for little against all the clothes that slipped over the head, used novelty closings, hooked closed, or-after 1930 - zippered..$^{34}$ Fresh-water pearl buttons could achieve a diameter of one inch in the heyday of the mussels, but by 1921 they were being bred rapidly; they may not have been able to reach more than the three-inch diameter of an average "niggerhead" shell. Buttonmakers could not cut fashionably large buttons from the smallish shells and realize a profit. Fresh-water pearl buttons might still grace men's shirts and women's lingerie, but their fashionable role in women's clothes vanished and with it the "salad days" of the Muscatine industry.

34. Vogue, 1912-1939 passim. 
Copyright of Annals of Iowa is the property of State of Iowa, by \& through the State Historical Society of Iowa and its content may not be copied or emailed to multiple sites or posted to a listserv without the copyright holder's express written permission. However, users may print, download, or email articles for individual use. 